Vol. XXIII No 2017

\title{
DESIGNING A LEGAL ENGLISH COURSE FOR MASTER OF LAWS STUDENTS
}

\author{
Simina BADEA \\ University of Craiova, Craiova, Romania \\ siminabadea@yahoo.com
}

\begin{abstract}
Over the last years, universities have diversified their educational offer, understanding and emphasizing the role of foreign languages in enhancing both personal and professional growth. Study programmes at undergraduate level have a mandatory foreign language component and there is a tendency to provide master's programmes in foreign languages especially in the field of law, business, political sciences, international relations, etc. In this framework, the paper attempts to identify and present the steps to be taken in designing a legal English course for students who complete their Master of Laws (LLM) degree in Human Rights. The focus is on the development of such a course as an essential element of a syllabus. The paper discusses the subject content of the course, i.e. the areas within each topic meant to improve and expand the students' specialist vocabulary which will further enable them to operate effectively in the field of human rights, the language content and the language skills which must be practised, while also analyzing subject-based materials and language materials.
\end{abstract}

Keywords: educational offer, syllabus and course design, LLM students, legal English course, human rights

\section{Introduction}

A few decades ago, the major role of English as the international language of legislation, politics, trade, tourism, marketing, etc. was disregarded, especially at the academic level [1]. Fortunately, a radical change has occurred in the role of universities and, over the last years, they have also understood the importance of foreign languages, in particular of English, in enhancing both personal and professional growth. This has led to a diversification of their educational offer, which means that study programmes at undergraduate level have a mandatory foreign language component (and most often a second optional such component) and there is a tendency to provide master's programmes in foreign languages in the field of law, business, political sciences, international relations, etc. In this framework, the paper attempts to identify and present the steps to be taken in designing a legal English course for students who complete their LLM (Master of Laws) degree in Human Rights.

\section{Context and premises: a master's programme in human rights}

The master's programme in the field of human rights, in the French language, is a new study programme at the Faculty of Law, University of Craiova.

In general, master's programmes may be of three types: 1. professional programme, mainly aiming at developing professional skills; 2. research programme, focusing on the development of research skills; 3 . didactic programme [2]. The programme in question is preponderantly a research one. As stated in the educational offer, most members of the teaching staff have the right to coordinate $\mathrm{PhD}$ theses, which opens the way to advanced research, to completing doctoral studies.

In the first semester, students study (in French) disciplines relating to the 
philosophy of human rights, protection of civil and political rights, international criminal law, freedom and security, discrimination, conflicts of jurisdiction and of laws. They also study legal French or legal English.

During the second semester, the areas of study cover the protection of economic, social and cultural rights, humanitarian law in crisis situations, conflicts between human rights and domestic law, conflicts at European and international level regarding human rights. Optionally, students may participate in European contests or in international seminars.

\section{Designing a legal English course for LLM students \\ 3.1. Stages}

Graves identifies six steps in the development of a systematic ESP syllabus:

- conducting needs analysis

- determining the goals and objectives of the course

- conceptualizing the content

- selecting and developing materials and activities

- organizing the content and activities

- evaluating [3].

The focus of this study is on the development of a legal English course as an essential element of a syllabus. We will insist on the first four steps out of the six mentioned by Graves.

\subsection{An insight into needs analysis}

"Such factors as the reasons for learning, anticipated place and time of usage, those whom the speaker will likely interact with, activities involved, skills needed (e.g. listening, speaking, reading, writing, translation) are all taken into consideration in what could be called a "needs analysis"' [4].

Lesiak-Bielawska notes that over time, the concept of needs analysis has been enlarged, including besides target situation analysis, a series of extra elements, such as subjective needs analysis, present situation analysis, learning needs analysis, discourse/ genre analysis and means analysis [5]. After
1990, a more genre-analytic perspective opened the way to a more empirical research into student needs. After 2000, we have witnessed a tendency to use task-based needs analysis to collect quality data and to resort to expert knowledge [6].

The structure of an ESP syllabus highly depends on the assessment of students' purposes and needs and the functions for which English is required. Linguists and teachers are more and more concerned with students' motivation and the analysis of their needs, because this will lead to the selection of the methods, techniques and materials used in class.

Considering that, within the master's programme in human rights, 'Legal English' is a seminar with the status of a practical course, the designing of such a course should harmonize with the overall characteristics and objectives of the programme and should contribute to the improvement of the students' language skills, as well as the enhancement of their specialist vocabulary and research skills which will further enable them to carry out advanced research at $\mathrm{PhD}$ level.

An important step in this direction refers to the acquisition of the terminology covering various aspects of human rights so that students can consult academic materials, i.e. books, articles, treatises, monographs, or international legislation and case law, which involves the development of reading skills. They also need to understand an interlocutor or lecturer if they participate, for instance, in an international conference, and to speak to such an interlocutor, in other words, to communicate in a professional legal environment (i.e. developing listening and speaking skills). Communication in writing is a capital need at the academic level. LLM students attend courses at partner universities abroad, take part in international conferences or contests, and, according to the profile of master's programmes in foreign languages which generally focus on the research component in Romania, they need to develop academic 
literacies for research purposes and second language thesis and dissertation writing.

\subsection{Objectives of the course}

After an overview of the students' needs, a teacher usually establishes a set of objectives which should be defined and generated in accordance with the quality of the skills and competences that students should acquire. This will influence the selection of the means for the attainment of these aims, i.e. teaching methods, materials, activities.

Before setting the objectives of the 'Legal English' course, it is appropriate to take into account that, at the end of the programme, students must acquire the following competences, which are consistent with those provided by the study of each discipline within the programme:

a) Professional competences:

1. Linguistic skills at the academic level for the appropriate use of legal concepts, theories, paradigms and methodologies.

2. A level of academic proficiency in the English language.

3. Knowledge of specialist vocabulary in the field of human rights.

4. In-depth understanding of grammatical structures specific to legal English.

5. Ability to analyze relevant texts related to the studies.

6. Oral and written communication skills.

b) Transversal competences:

1. Specific skills for teamwork and for the implementation of effective teamwork techniques (with interdisciplinary elements).

2. Oral and written communication skills in English and effective use of communication and information resources, as well as professional training resources.

3. Ability to identify the rules applicable to a specific legal situation in order to achieve a practical objective and to present orally and in writing the legal analysis of a relevant situation.

The general objective of the practical course is the development of the linguistic skills necessary to communicate in English at the university level, in the field of law, and, more specifically, in the area of human rights.

At the professional level, the specific objectives are to develop the capacity to organize legal knowledge and to use specific techniques of interpretation, a process favoured by the acquisition of the specific language skills required for academic studies.

At the transversal level, the specific objectives are to deepen and broaden the knowledge of legal English, both written and spoken through practical vocabulary exercises, analysis of legal texts and documents on human rights topics, while implementing effective teamwork techniques and making use of communication resources.

Although one of the objectives relates to the understanding and use of specific grammatical structures that deepen the knowledge of legal English, in terms of language content, a prerequisite of the course is a language level of B2 (upper intermediate), or at least B1.

Students are expected to operate with the basic verb tenses, conditionals, the passive voice, modal verbs, quantifiers and determiners, linking words, etc.

As far as language skills are concerned, the prerequisites refer to the students' ability to keep up a simple conversation and follow a talk on a legal topic, to scan less complex legal texts for relevant information and understand the main ideas, to make notes and express opinions orally and in writing starting from a text of medium difficulty.

The students' evolution will be reflected in their ability, at the end of the programme, to handle a wider range of conversational situations and contribute effectively to courses and seminars, to understand more sophisticated materials, especially those in the field of human rights, to write on academic topics with few errors in structure and spelling and with idiomatic ease of expression, to carry out research in English. 


\subsection{Conceptualizing the content of the course}

The subject content of the course may be structured as follows (for two hours a week during one semester): A Human Rights Approach (legal framework, background, fundamentals); International Institutional Framework (international human rights law v. domestic law; regional mechanisms for the protection of human rights; international instruments and standards); European Convention on Human Rights (human rights in terms of specialist vocabulary and specific grammatical structures); European Court of Human Rights (general presentation, composition of the Court, judges, sections, general practice, Grand Chamber, case-law analysis, translations, research reports, hearings, applications, rules, delivery of judgments); Remedy in Human Rights Law (practices, grievance mechanisms); Defending Civil Rights, Women's Human Rights (international human rights framework for guaranteeing women's rights; economic, social, political rights of women; violence against women); Children's Human Rights (international human rights framework for protecting children's rights; development of international child law; current issues); Freedom and Its Limits; Third Generation Rights.

\subsection{An overview of activities}

Activities should be designed and structured so that students will be encouraged to think independently and express their own opinions. Subject-based materials used in class should be authentic and rely on prestigious academic writings, case law and legislation, case reports, press releases and even official sites of institutions. All these materials are usually selected and explored in compliance with the content areas of the course. The reading stage is necessarily followed by the clarification of legal terms or other words and phrases that students are not familiar with, by quizzes and exercises that ensure the proper understanding of the text and the practice of new vocabulary, and finally, by discussions, debates and written assignments.

The practice of grammatical structures specific to legal language is usually integrated into the practice of language skills in such a course. It is necessary to practise both receptive skills (reading and listening) and productive skills (writing and speaking) in the context of human rights.

It would be very difficult to prioritise one set of skills above another, but the primary criterion is that the activities should mirror real-life and career situations.

Students should be helped to overcome certain difficulties that prevent them from enhancing their language skills. They should identify the causes that make them reluctant to speak, especially during a seminar or tutorial.

If at undergraduate level, more precisely in the $1^{\text {st }}$ and $2^{\text {nd }}$ year of the bachelor's programme, students become familiar with the core vocabulary of the main law branches, at LLM level, they evolve and the development of a wide range of skills involved in research becomes essential. They should be taught how to produce a dissertation or a paper in a foreign language, namely how to:

- select a topic which will be converted into a research question

- organize the production of the dissertation into stages

- find statutory instruments, case reports, legislation, either domestic or European, in a library and online

- find out whether there is any law on a particular topic

- determine whether a piece of legislation is in force

- locate the official texts of treaties, conventions, etc.

- avoid plagiarism

- use online library catalogues and legal bibliographies

- make reasoned choices about the language and style used in writing an 
academic paper, in preparing coursework

- provide references accurately, etc [7].

\section{Conclusion}

A Master Degree's programme in a foreign language represents a great enhancer of career opportunities. Designing a course for such a programme is a complex process that requires, first of all, a careful needs analysis. Teachers should understand their students' motivation and be realistic when setting the objectives of the course, conceptualizing the subject content, selecting and organizing the materials and activities used in class, because students need guidance, but they should also preserve their independence and remain creative, they should experience the exploration of their own resources.

\section{References}

[1] E. Alcaraz Varó, B. Hughes, Legal Translation Explained, Routledge, 2014, p. 1.

[2] Ioan Ciochină-Barbu, Dreptul muncii. Curs universitar, Bucureşti, Editura Hamangiu, 2012, pp. 39-40.

[3] K. Graves, Teachers as Course Developers, Cambridge, Cambridge University Press, 1996.

[4] Jane Lung, A blended needs analysis, in Vijay Bhatia and Stephen Bremner (eds.), The Routledge Handbook of Language and Professional Communication, pp. 257-273, Routledge, 2014, p. 257.

[5] Elżbieta Danuta Lesiak-Bielawska, English for Specific Purposes in Historical Perspective, English for Specific Purposes World, vol. 46, pp. 1-23, 2015, p. 6.

[6] M.H. Long, Methodological issues in learner needs analysis, in M.H. Long (ed.), Second Language Needs Analysis, pp. 19-76, Cambridge, Cambridge University Press, 2005; R. Gilabert, Evaluating the use of multiple sources and methods in needs analysis: a case study of journalists in the Autonomous Community of Catalonia (Spain), in M.H. Long (ed.), Second Language Needs Analysis, pp. 182-99, Cambridge, Cambridge University Press, 2005.

[7] Emily Finch, Stefan Fafinski, Legal Skills (second edition), Oxford, Oxford University Press, 2009. 